\title{
Comparison of Appendicitis Scoring Systems in Pediatric Patients
}

\section{Çocuk Hastalarda Apandisit Puanlama Sistemlerinin Karşılaştırılması}

\author{
Dilknur Banlı Cesur', @Sinem Sarı Gökay² \\ IUniversity of Health Sciences, Adana City Training and Research Hospital , Department of Pediatric Surgery, Adana, Turkey \\ ${ }^{2}$ Adana City Training and Research Hospital, Department of Pediatric Emergency,Adana, Turkey
}

\begin{abstract}
Background: Appendicitis is one of the most common causes of emergency department (ED) admission among pediatric patients, and the most common cause of abdominal pain requiring surgical intervention. The present study aimed to measure the success of three different appendicitis scoring systems in patients who were operated due to appendicitis upon presenting at the pediatric ED with acute abdominal pain.

Material and Method: The study included a total of 226 patients who were admitted to Pediatric Emergency Department and who underwent an appendectomy between December 2018 and May 2019. Through a retrospective review of patient files; age, gender, clinical findings, laboratory results, Pediatric Appendicitis Score (PAS), Lintula score, Acute Inflammatory Response (AIR) score, ultrasonography (USG) findings and pathology results of the patients operated due to appendicitis were recorded.

Results: A total of 226 patients were included in the study, with a mean age of $11.6 \pm 3.66(1-17)$ years, and $57.1 \%(n=129)$ of the patients were female and $42.9 \%(n=97)$ were male. The pathology results were evaluated under three categories: suppurative (phlegmonous) appendicitis, 74.3\%; perforated appendix, 9.7\%; and reactive lymphoid hyperplasia, $15.9 \%$. The cut-off values $>3$ for AIR, $>7$ for PAS and $>15$ for Lintula were found statistically significant. Among the three scoring systems, Lintula had the highest sensitivity (91.5\%) and PAS had the highest specificity (69.4\%).

Conclusion: Although scoring systems are used to diagnose appendicitis, the selected cut-off values for the scoring systems have an effect on the results. Patients with a PAS score of $\geq 7$ were found to have more significant appendicitis results. We believe that PAS is likely to be a preferred scoring system in pediatric patients, especially under busy ED conditions; however, further studies with larger populations are needed to develop scoring systems that will guide physicians to establish a final diagnosis.
\end{abstract}

Keywords: Appendicitis, scoring systems, pediatric patients

\section{Öz}

Amaç: Çocuklarda acile en sık başvuru nedenlerinden olan ve en sık acil cerrahi girişim gerektiren karın ağrısı nedeni akut apandisittir Çocuk acil servisine akut karın ağrısı ile başvuran hastalarda apandisit şiddetini değerlendirmek ve üç farklı skorlama sisteminin başarısını ölçmek amaçlanmıştır.

Gereç ve Yöntem: Bu çalışmada Aralık 2018- Mayıs 2019 tarihleri arasında Adana Şehir Eğitim ve Araştırma Hastanesi Çocuk Acil servisine başvuran ve apendektomi yapılan hastalar değerlendirildi. Çalışma için Adana Şehir Eğitim ve Araştırma Hastanesi etik kurul onayı alındı. Çalışmaya 226 hasta dahil edildi. Apandisit için ameliyat edilen hastaların PAS, Lintula, AIRS skorları, ultrasonografi bulguları (usg) ve Patoloji sonuçları kaydedildi. Apandisit cerrahi ve patoloji sonuçları dayanarak doğrulandı. Apandisit dışındaki nedenler için tesadüfi apendektomi yapılan, diğer hastalıklar nedeni ile hastanede yatış sırasında apandisit teşhisi konan veya tıbbi kayıtları eksik olan hastalar çalışma dışı bırakıldı.

Bulgular: Bu çalışmaya toplam 226 hasta dahil edildi. Hastaların yaş ortalaması 11,6 3,66 (1-17 yıl) yıldı. Hastaların \%57,1 (129) 'si kadın, $\% 42,9$ (97)'u erkekti. Hastaların \%17,3 (39)'ünde usg yapılamamıştır. USG yapılan 187 hastanın \%67,3' ünde apendiks lümen çapı 7 mm ve üzerinde, $\% 15,5^{\prime}$ inde ise $6 \mathrm{~mm}$ ve altında idi. Patoloji sonuçları üç grupta değerlendirildi. Hastaların \%74,3'ü süpüratif, flegmenöz apandisit, \%9, $7^{\prime}$ si ise perfore apandisit, \%15,9'u reaktif lenfoid hiperplazi idi. AIRR, Lintula, PAS skor grupları düşük ihtimal, orta ihtimal ve yüksek ihtimal akut apandisit olarak gruplara ayrıldı.

Sonuç: Apandisit tanısını koymada skorlama sistemlerinden faydalanılmakla birlikte skorlamaların seçilen cut off değerleri sonuçları etkilemektedir. Çalışmamızda skorlamalar arasında PAS 7 ve üzerinde olan hastalarda daha anlamlı sonuçlar ortaya çıkmıştır ve özellikle yoğun acil şartlarda PAS ın çocuklarda öncelikli kullanılabilir skorlama olabileceğini düşünmekle birlikte kesin tanıya hekimi yönlendirebilecek geniş populasyonlarda skorlama sistem çalışmalarının yapııması gerektiğini düşünmekteyiz.

Anahtar kelimeler: Apandisit, teşhis skoru, çocuk

Corresponding (illetişim): Illknur Banlı Cesur, University of Health Sciences, Adana City Training and Research Hospital, Department of Pediatric Surgery, Adana, Turkey

E-mail (E-posta): zzcesur@yahoo.com

Received (Geliş Tarihi): 08.02.2021 Accepted (Kabul Tarihi): 24.03.2021 


\section{INTRODUCTION}

Appendicitis is one of the most common causes of emergency department (ED) admission among pediatric patients, and is the most common cause of abdominal pain requiring surgical intervention. ${ }^{[1]}$ The clinical manifestation of appendicitis is variable, from a simple inflamation to a wide range of pathologies, including perforation, within 24-36 hours after the onset of complaints. It is difficult, however, to determine the course of symptoms in an agitated and irritable child, due especially to the fact that the symptoms of appendicitis - such as abdominal pain, vomiting and uneasiness - may also indicate a number of other diseases. Furthermore, children may be unable to effectively express their complaints, appendicitis is associated with high morbidity and mortality when not diagnosed and treated in the early stage. [2] This has made various scoring systems, which have been developed to support or exclude the diagnosis of eppendicitis, become more important in recent years.

The objective of the present studies to evaluate the pediatric appendicitis score (PAS), Lintula score and acute inflammatory response (AIR) score of for appendicitis - one of the most common causes of surgery in pediatric patients, and is also associated with high mortality when not early diagnosed-and to determine whether there is a preferred scoring system for establishing the diagnosis. ${ }^{[3-7]}$

\section{MATERIALS AND METHOD}

We retrospectively assessed 226 patientswho presented and had appendectomy at the Adana City Training and Research Hospital Pediatric Emergency Department between December 2018 and May 2019. The patient files were used to obtain data regarding the age, gender, disease symptoms, physical examination and laboratory findings (WBC and neutrophil counts, CRP levels), USG findings and pathology results of the patients operated due to appendicitis along with the PAS, Lintula and AIR scores.The same clinician made the scoring assessment of all cases.

Appendicitis diagnoses were confirmed through surgical findings and pathology results. Group 1 was appendicitis (suppurative, phlegmonous, acute appendicitis), group 2 was perforated appendicitis, group 3 was reactive lymphoid hyperplasia. The exclusion criteria were as follows: (a) appendectomy for reasons other than appendicitis , (b) elective coincidental appendectomy, (c) appendicitis diagnosis while hospitalized for other reasons, and (d) incomplete medical records.

\section{Statistical Analysis}

The study data were analyzed using the IBM SPSS version 23.0 software package. Besides descriptive statistical methods expressed a (mean, standard deviation, frequency, minimum and maximum), a Student's t-test was used for the comparison of quantitative data; Fisher's Exact and Chi-square tests were for the comparison of qualitative data; and a Receiver Operating Characteristic (ROC) analysis was conducted for the PAS, Lintula and AIR scores. The results were used to determine the cut-off values, specificity, sensitivity, and positive and negative predictive values of each scoring system. A p-value of $<0.05$ was considered statistically significant.

\section{RESULTS}

A total of 226 patients were included in the study, with a mean age of $11.6 \pm 3.66(1-17)$ years, and $57.1 \%(n=129)$ of the patients were female and $42.9 \%(n=97)$ were male. Of the total, $17.3 \%$ $(n=39)$ of the patients did not undergo a USG examination. Among the remaining 187 patients, the diameter of the lumen was $\geq 7 \mathrm{~mm}$ in $67.3 \%$ and $\leq 6 \mathrm{~mm}$ in $15.5 \%$. Pathology results were evaluated under three categories: suppurative (phlegmonous) appendicitis, 74.3\%; perforated appendix, 9.7\%; and reactive lymphoid hyperplasia, 15.9\%. The patients were divided into three groups based on the results of each scoring system, as low, moderate and high risk (Table 1).

\begin{tabular}{lc} 
Table 1. Components of the Pediatric Appendicitis Score (PAS) & \\
\hline Signs/symptoms & Point value \\
\hline Nausea/emesis & 1 \\
Anorexia & 1 \\
Migration of pain to RLQ & 1 \\
Low-grade fever $\left(\geq 38.0^{\circ} \mathrm{C}\right.$ ) & 1 \\
RLQ tenderness & 2 \\
RLQ tenderness to cough, percussion, or hopping & 2 \\
Leukocytosis $\left(>10,000 / \mathrm{mm}^{3}\right.$ ) & 1 \\
Left shift (neutrophilia $>75 \%)$ & 1 \\
Total & 10 \\
\hline Abbreviations: RLQ, right lower quadrant. & \\
\hline
\end{tabular}

A ROC analysis was conducted to compare the pathology results with the scoring system results. The mean AIR score was $4.99 \pm 1.87$. The diagnosis of appendicitis was found statistically significant when the cut-off value of AIR was 3, with a sensitivity of $83.1 \%$ and specificity of $61.1 \%(p<0.05)$. The positive and negative predictive values of the AIR scoring system were $91.9 \%$ and $40.7 \%$, respectively (Figure 1, Table 2).

The mean PAS score was $8.18 \pm 1.29$. It was found that the cut-off value from the ROC analysis and ROC curve yielded accurate results at a rate of $82.1 \%$. Patients with a PAS score $>7$, which was the cut-off value of PAS, were diagnosed with appendicitis, with a sensitivity of $82.1 \%$ and specificity of $69.4 \%$ ( $p<0.05$ ). The positive and negative predictive values of the PAS scoring system were $93.4 \%$ and $42.4 \%$, respectively (Figure 2, Table 2).

The mean Lintula score was $19.53 \pm 4.38$. It was found that the cut-off value of Lintula from the ROC analysis and ROC curve yielded accurate results at a rate of $72.3 \%$. The cut-off value for Lintula was calculated as 15 with a sensitivity of $91.5 \%$ and a specificity of $38.8 \%$. The positive and negative predictive values of the Lintula scoring system were $88.8 \%$ and $46.7 \%$, respectively. The results were statistically significant $(p<0.05$, Figure 3, Table 2). 
The comparison of appendix length as measured on USG with the pathology results revealed suppurative (phlegmonous) appendicitis to be more common in the patient group where lumen diameter of the ppendix was $\geq 7 \mathrm{~mm}$. However, this difference was not statistically significant.

The pathology results revealed patients with a perforated appendix to have statistically significantly higher Lintula, PAS and AIR scores ( $p<0.05$, Table 3 ).

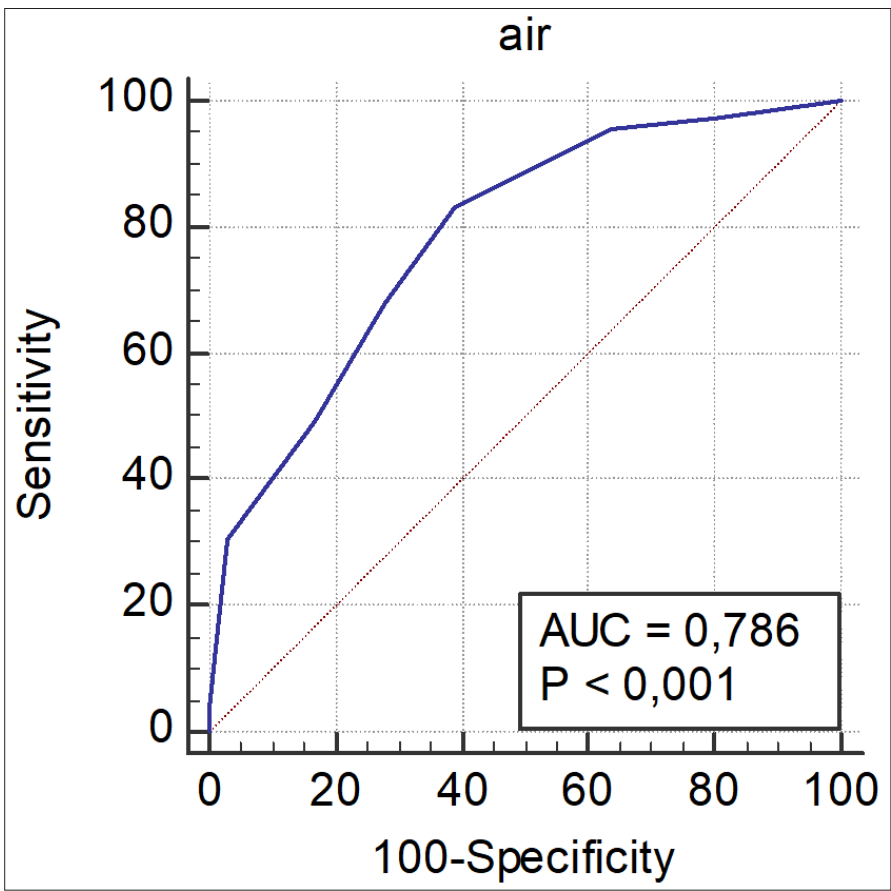

Figure 1. ROC curve of AIR scores

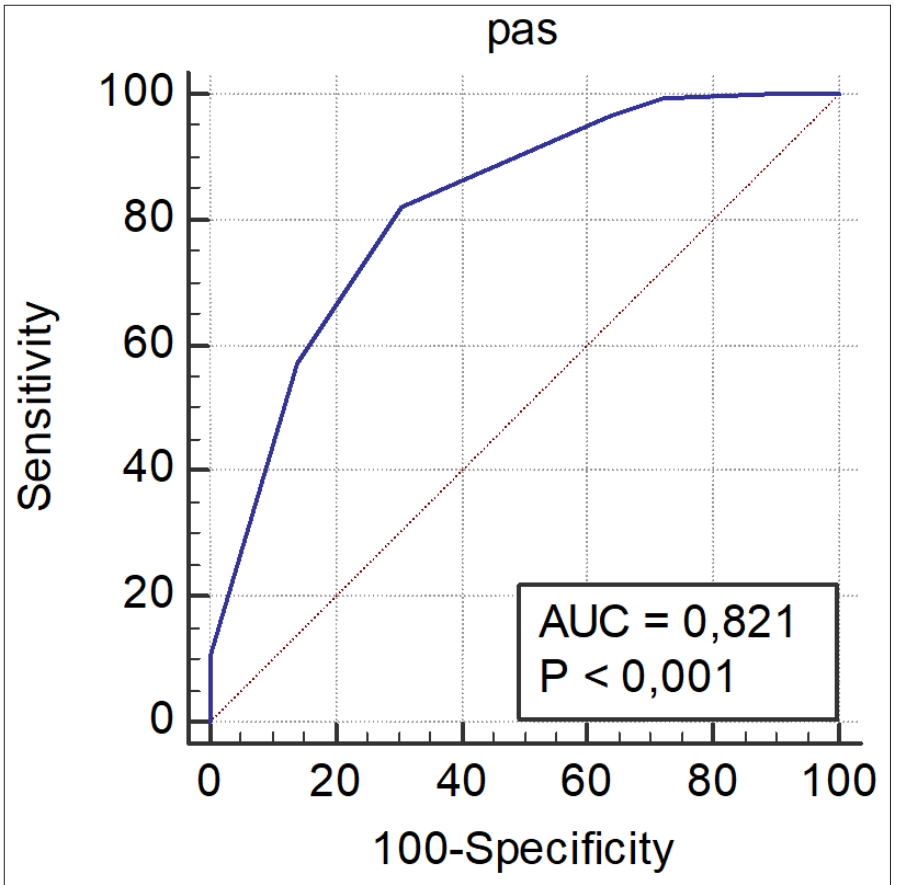

Figure 2. ROC curve of PAS scores

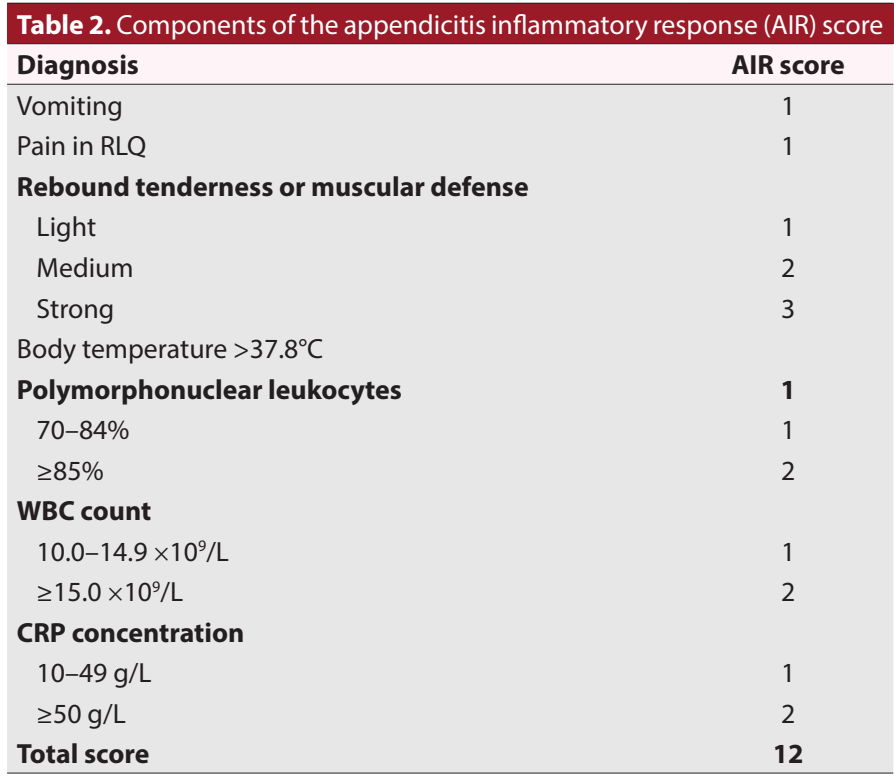

\section{Table 3. Lintula appendicitis score.}

Parameter

Score

Male gender

2
2
4
2
4
3
4
4
7
32

Intensity of pain severe

Relocation of pain

Vomiting

Pain in RLQ

Fever $\geq 37.5^{\circ} \mathrm{C}$

Guarding

Absent, tinkling, high-pitched bowel sounds

Rebound tenderness

Total score

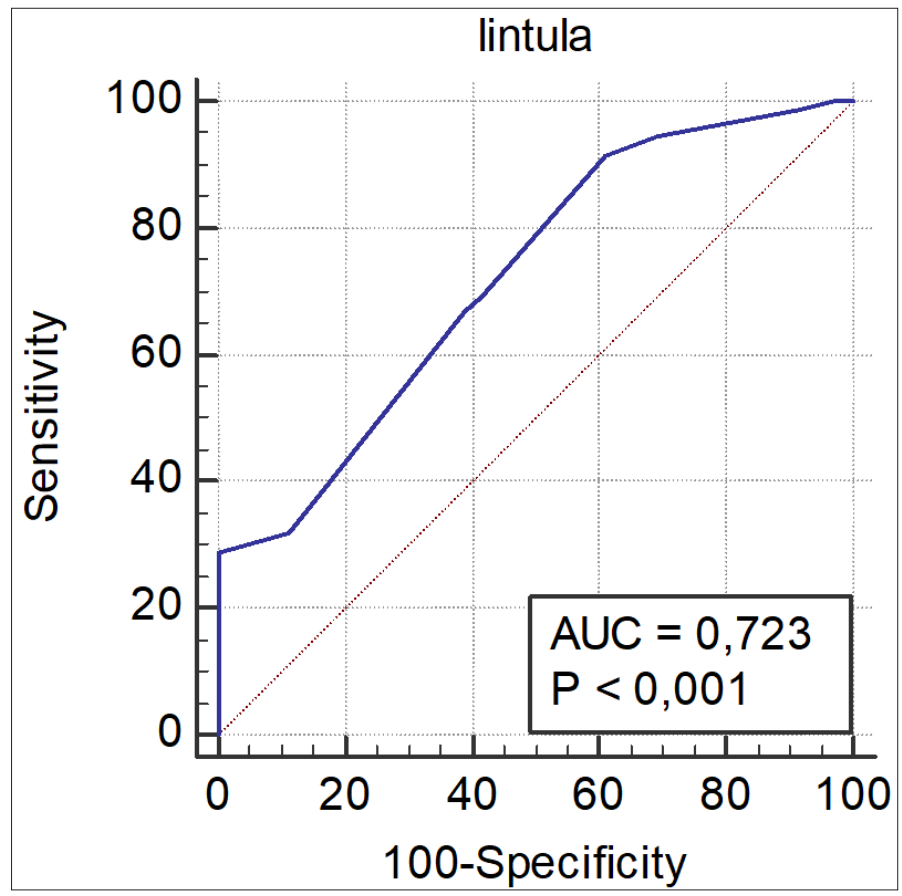

Figure 3. ROC curve of Lintula scores 


\begin{tabular}{|c|c|c|c|}
\hline Parameters & & Mean \pm SD & Min-Max \\
\hline Age & & $11.60 \pm 3.66$ & $1-17$ \\
\hline Lintula & & $19.53 \pm 4.38$ & $6-35$ \\
\hline PAS & & $8.18 \pm 1.29$ & $3-11$ \\
\hline \multirow[t]{2}{*}{ AIR } & & $4.99 \pm 1.87$ & $1-9$ \\
\hline & & $\begin{array}{l}\text { Frequency } \\
\text { (n) }\end{array}$ & $\begin{array}{c}\text { Percentage } \\
(\%)\end{array}$ \\
\hline \multirow{2}{*}{ Gender } & Male & 129 & 57.1 \\
\hline & Female & 97 & 42.9 \\
\hline \multirow{2}{*}{ USG } & $<6 \mathrm{~mm}$ & 35 & 15.5 \\
\hline & $\geq 7 \mathrm{~mm}$ & 152 & 67.3 \\
\hline \multirow{3}{*}{ Pathology } & Reactive lymphoid hyperplasia & 36 & 15.9 \\
\hline & $\begin{array}{l}\text { Acute appendicitis - } \\
\text { suppurative/phlegmonous }\end{array}$ & 168 & 74.3 \\
\hline & Perforated appendix & 22 & 9.7 \\
\hline \multirow{3}{*}{ AIR } & $0-4$ & 87 & 38.5 \\
\hline & $5-8$ & 135 & 39.3 \\
\hline & $9-12$ & 5 & 2.2 \\
\hline \multirow{3}{*}{ Lintula } & $\leq 15$ & 30 & 13.3 \\
\hline & $16-20$ & 131 & 58.0 \\
\hline & $\geq 21$ & 65 & 28.8 \\
\hline \multirow{3}{*}{ PAS } & $0-4$ & 4 & 1.8 \\
\hline & 5 & 7 & 3.1 \\
\hline & $\geq 6$ & 215 & 95.1 \\
\hline
\end{tabular}

\section{DISCUSSION}

Even though $80 \%$ of cases of appendicitis can be diagnosed through anamnesis and physical examination, and despite the availability of supportive laboratory and radiologic examinations, definitive appendicitis diagnoses are still an important issue in pediatric patients. ${ }^{[8,9]}$ The increased complication risk associated with delayed diagnosis in children makes it vital that more efficient diagnostic tools be developed. ${ }^{[10,11]}$

Appendicitis scoring systems are helpful to establish a diagnosis and make a surgical decision in cases suspected of appendicitis based on patient history and physical examination results. Among these, the Pediatric Appendicitis Score (PAS) is a system developed to facilitate appendicitis diagnosis in pediatric patients, based on simple non-invasive clinical and laboratory assessments. It is easy to teach and apply, without any need for invasive tests. . Patients with PAS scores between 0 and 4 can be monitored in pediatric emergency departments and discharged with possible readmission in case of persistent symptoms. Patients with PAS scores of 5-6 may benefit from radiological examinations. Samuel evaluated the clinical findings of 1,170 patients aged 4-15 and reported a PAS score of $\geq 6$ to be associated with a high probability of appendicitis. [12] A PAS score $\geq 7$ indicated a high risk of appendicitis and such patients were recommended to have surgery without any other imaging techniques. The negative appendectomy (NA) rate was $1.8 \%$ in these patients, i.e. significantly lower than in most studies. ${ }^{[13]}$ Several authors have proposed different cut-off values for PAS. For instance, Schneider et al. evaluated 588 suspected appendicitis patients (mean age: 11.9 years) and found the sensitivity and specificity of PAS $\geq 6$ to be $82 \%$ and $65 \%$, respectively. In two other studies, the sensitivity and specificity of PAS $\geq 7$ were found to be $97.6-100 \%$ and 92-96\%, respectively. ${ }^{[5,13]}$ In the present study, the sensitivity and specificity of PAS $>7$ were found to be $82.1 \%$ and $69.4 \%$, respectively.

Most of the appendicitis scoring systems have been initially developed for adult populations. Although these same tools are also used for pediatric cases, more pediatric-focused appendicitis scoring systems are needed toprovide more accurate results, which has led researchers to provide new scoring systems specifically for pediatric population. One of such systems is the Lintula scoring system. However, as this 9-item scoring system includes also non-surgical appendicitis cases, it is not $100 \%$ reliable. Therefore, these scoring systems alone are insufficiently precise to steer surgery or discharge decisions, and need to be supported by repeated clinical examinations. Lintula et al. reported negative appendectomy rates to be significantly lower in patients with a score of $\geq 21 .^{[14]}$ Yoldas et al. evaluated the results of 156 patients and determined the sensitivity and specificity to be $88.1 \%$ and $91.6 \%$, respectively. ${ }^{[15]}$ In the present study, the Lintula scoring system had the highest sensitivity value $(91.5 \%$ for a score of $>15$ ), but the lowest specificity (38.8\%) among the three appendicitis scoring systems tested. Accordingly, we conclude that the effectiveness of these scoring systems is associated with the determined cut-off values. The appendicitis scores should be combined with repeated clinical examinations. Using effective scoring systems can help support clinical diagnoses and can reduce negative appendectomy rates.

One disadvantage of the Lintula and PAS scoring systems is that they contain somewhat subjective assessment criteria. In contrast, the criteria of the AIR scoring system are more objective and practical for the pediatric patient population, as it excludes such subjective criteria as nausea, loss of appetite and the localization of pain. Macco et al. evaluated 747 patients and reported AIR to have superior positive predictive value and specificity when compared to other scoring systems.16 In the present study, the AIR score yielded more significant results in the perforated appendix patients, which we attribute to the CRP values included in the scoring, and suggest that this can be useful in preventing unnecessary use of imaging techniques.

Appendicitis scoring systems, as combined with following repeated clinical examinations and imaging techniques are used as tools to improve decision-making and appendicitis prediction in selected patients. Such systems also support ED decisions and minimize malpractices. Using scoring systems in clinical practice can even prevent unnecessary hospitalization.

An effective scoring system may serve as a tool to confirm the diagnosis, to determine which pediatric patients require additional diagnostic imaging, and to guide clinical monitoring or discharge decisions. Consistent with the literature, the present study determined that patients with a PAS score of $>7$ were most likely to be diagnosed with appendicitis, and we concluded that PAS would be a more supportive scoring system when compared to Lintula and AIR scoring systems. 


\section{CONCLUSION}

There are still challenges in establishing a definitive appendicitis diagnosis, which include the unknown nature of an optimal assessment, the lack of a method with a $100 \%$ prediction rate and the presence of deficiencies in all scoring systems. . The use of scoring systems will be beneficial in busy ED conditions, although further studies involving larger populations are needed to improve and develop scoring systems that will aid in the provision of definitive diagnoses.

\section{ETHICAL DECLARATIONS}

Ethics Committee Approval: The study was granted ethical approval by the Adana City Training and Research Hospital Clinical Trials Ethics Committee (Date: 19/06/2019, Decision Number: 474).

Informed Consent: Written consent was obtained from all patients who participated in the study and their relatives.

Referee Evaluation Process: Externally peer-reviewed.

Conflict of Interest Statement: The author(s) declared no potential conflicts of interest with respect to the research, authorship, and/or publication of this article.

Financial Disclosure: The authors declared that this study has received no financial support.

Author Contributions: All of the authors declare that they have all participated in the design, execution, and analysis of the paper, and that they have approved the final version.

\section{REFERENCES}

1. Sivit C.J, et al. When appendicitis is suspected in children. Radiographics 2001. 21(1): 247-62; questionnaire 288-94.

2. Blakely ML,Williams R, Dassinger MS, et al. Early vs interval appandectomy for urg 2011;146:660-5.

3. Young P, [Appendicitis and its history]. Rev Med Chil 2014;142(5): 667-72.

4. Guraya SY, et al. Validity of leukocyte count to predict the severity of acute appendicitis. Saudi Med J 2005;26(12): 1945-7.

5. Schneider C, Kharbanda A, Bachur R. Evaluating appendicitis scoring systems using a prospective pediatric cohort. Ann Emerg Med 2007;29:778-84.

6. Shera AH, Nizami FA,Malik AA, Naikoo ZA, Wani MA. Clinical scoring system for diagnosis of acute appendicitis in children. Indian J Pediatr 2011;78:287-90.

7. Maclin CP, Rdcliffe GS, Merei JM, Stringer MD. A prospective evaluation of the modified Alvarado score for acute appendicitis in children. Ann R Coll Surg Engl 1997;79:203-5

8. Unlü C, de Castro SM, Tuynman JB. Evaluating routine diagnostic imaging in acute appendicitis. Int J Surg 2009;7(5):451-5.

9. Newman K, Ponsky T, Kittle K, et al. Appendicitis 2000:variability in practice, outcomes and resource utilization at thirty pediatric hospitals. J Pediatr Surg 2003;38:372-79.

10. Saucier A, Huang EY, Emeremni CA, Pershad J. Prospective evaluation of a clinical pathway for suspected appandicitis. Pediatrics 2014;133:88-95.

11. Sivit CJ,Siegel MJ, Applegate KE, Newman KD. When appandicitis is suspected in children.Radiographics 2001;21:247-62.

12. Samuel M. Pediatric appendicitis score. J Pediatr Surg 2002;37:877-81.
13. Goldman RD, Carter S, Stephens D, Atoon R, Mounstephen W, Langer JC. Prospective validation of the pediatric appendicitis csore. J Pediatr 2008;153:278-82.

14. Lintula H, Pesonen E, Kokki H, Vanamo K, Eskelinen M. A diagnostic score for children with suspected appendicitis.Langenbecks Arch Surg 2005;390:164-70.

15. Yoldas O, Karaca T, Tez M. External validation of Lintula score in Turkish acute appendicitis patients. International Journal Of Surgery 2012;10:2527.,

16. Macco S, Vrouenraets BC, de Castro SM.Evaluation of scoring system in predicting acute appendicitis in children. Surgery 2016;160:1599-1604. 